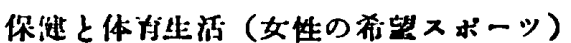

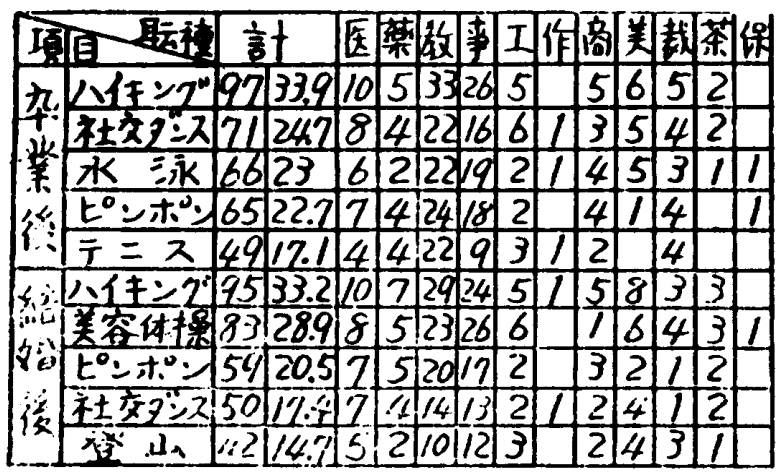

保健灭体青生活

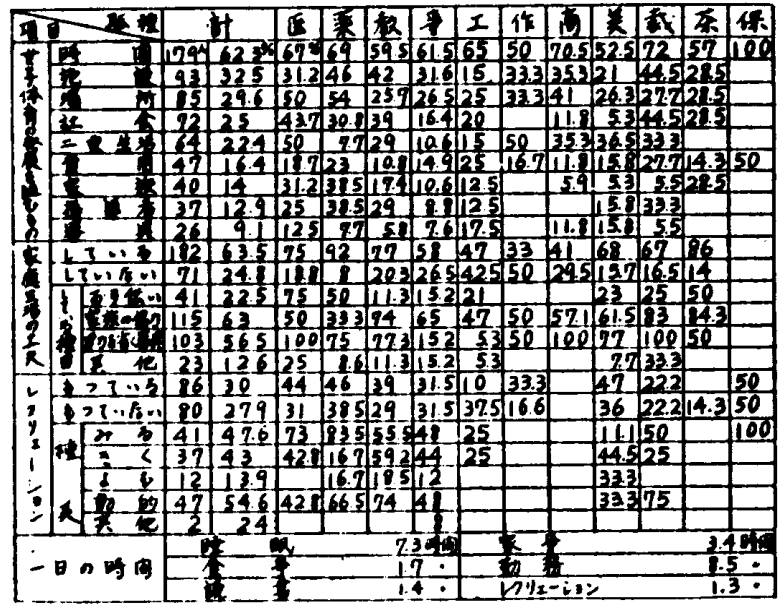

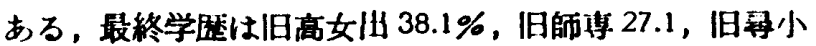
$25.1 \%$ 次にスボーッ歴は彼女達の現笛及び，将来の体育 生活を決定する固有の要帮であるがパレーボール．陸上 学校ダンス，徒业はどの年代にも共通した経駼である。 選手歴としては，校内が多いここうしたスポーツ歴をも つた，女性が，家庭と，職業とい5三つの杀件下にあつ て，現在も行つている者 $1 / 3$ に過ぎない，行つている種 目はハイキング，卢球，ダンス，水泳.動機として，趣味

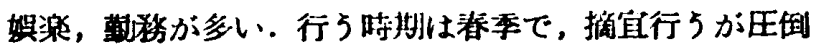
的である.月経との関係をみると過去にも現在も行了も

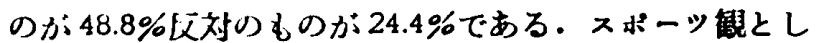
て趣味をるつもの多く㲜譏は，保健が多い。るたない理 由は時调がないが多い，家族特成で夫の状態では，健在 が半数をしぬ，死亡は案外多く，不幸な女性の多い、社会 ををみる・家族数会䛅 3.8 (平均) 老人はいずれる存命， 子供俚平均 7 人家族にスポーツをやらせる・が多い。保 健，趣味，レク，上やらせるという.夫のスポーッの関 心は王到的に赵味をしつが野球，水泳，ハイクが多い。

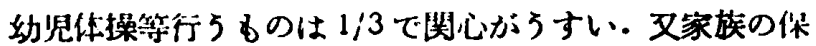

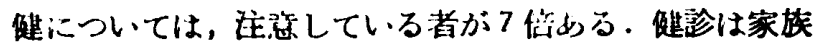
自己も半数にみたない，家庭生酒を工夫して体青生活に 努力しているものが 倍おり家族の協力や器具の工夫等 がそれを語る。
最後に女子体育の発展を阻むものとして，洔間に余裕 がないが倒的，施設，嵝所，社会。二重生活等刀順に

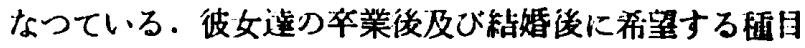
として，ハイキング，美容体操，卓球，社交ダンス，水 泳，庭球となつている。以上によつて，考えられる鞔は。 娥策をもつこれらの人の希望する杼目への接近した指道 法であらろ。

\section{Personality と可䱂遗択についての一考实}

$$
\text { （第一報） }
$$

甲南女子短期大学 木 村 昭 光

Personality と運動選択についての一考察（第一報） 性格の青代は後天的に，その個人が加盟した団体によ つて育戊せられるものとは，諸家の説く所であるが． ス ポーツの场においても，その属したクラプによつて望主 しい性格が育成せられ，文矮正䟻去され，更にはそれそ れの性格によつてスポーツを適当選択されるべきであ る.かつる見地から研究を始めた。

第一報として各種スポーックラプ冒の性格実態を把努

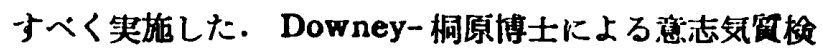
查を言考として行つた性格検查の結果を第一報として述 ベる。

調查刘象は本年は直接関保のある，女子スポーッ団体 (高校生，短大学生，会社従業員）計 459 名で释駼年数 2 年以上のるのを抽师して行つた。

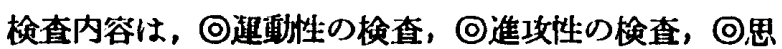
阐性検查の，の三部門に冝つて都合 12 問（1 閒の解答 時間 20 秒 5 分) の缺問紙法で， 1 回 40 人 50 人程度 を同封に笑施しその結果をWill Profile として，それ ぞれの型即た

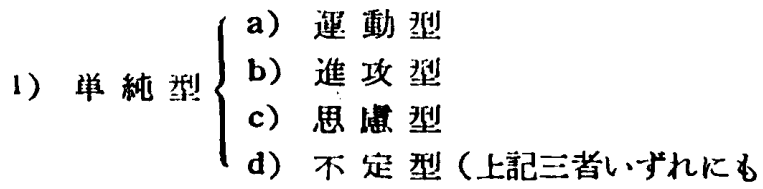
属しないもの)

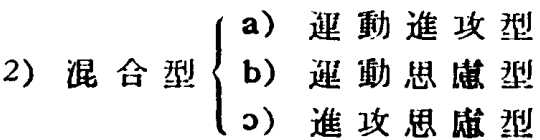
としてそれぞ れ分類し各スポーッと如何なる関係にあるかを見た。 （註. 第1因，第 2 図）その結果経験年数の少いもの程， 不定型に多く，経験年数の多いもの程，はつきりした型 があり，又技術面から見ても比較的传唀なる選手程，判 然とした型の佰向が見られた。

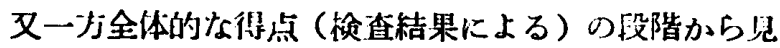
$\tau$,

(1) 皘 極型（平均优よい高いもの）

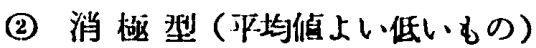



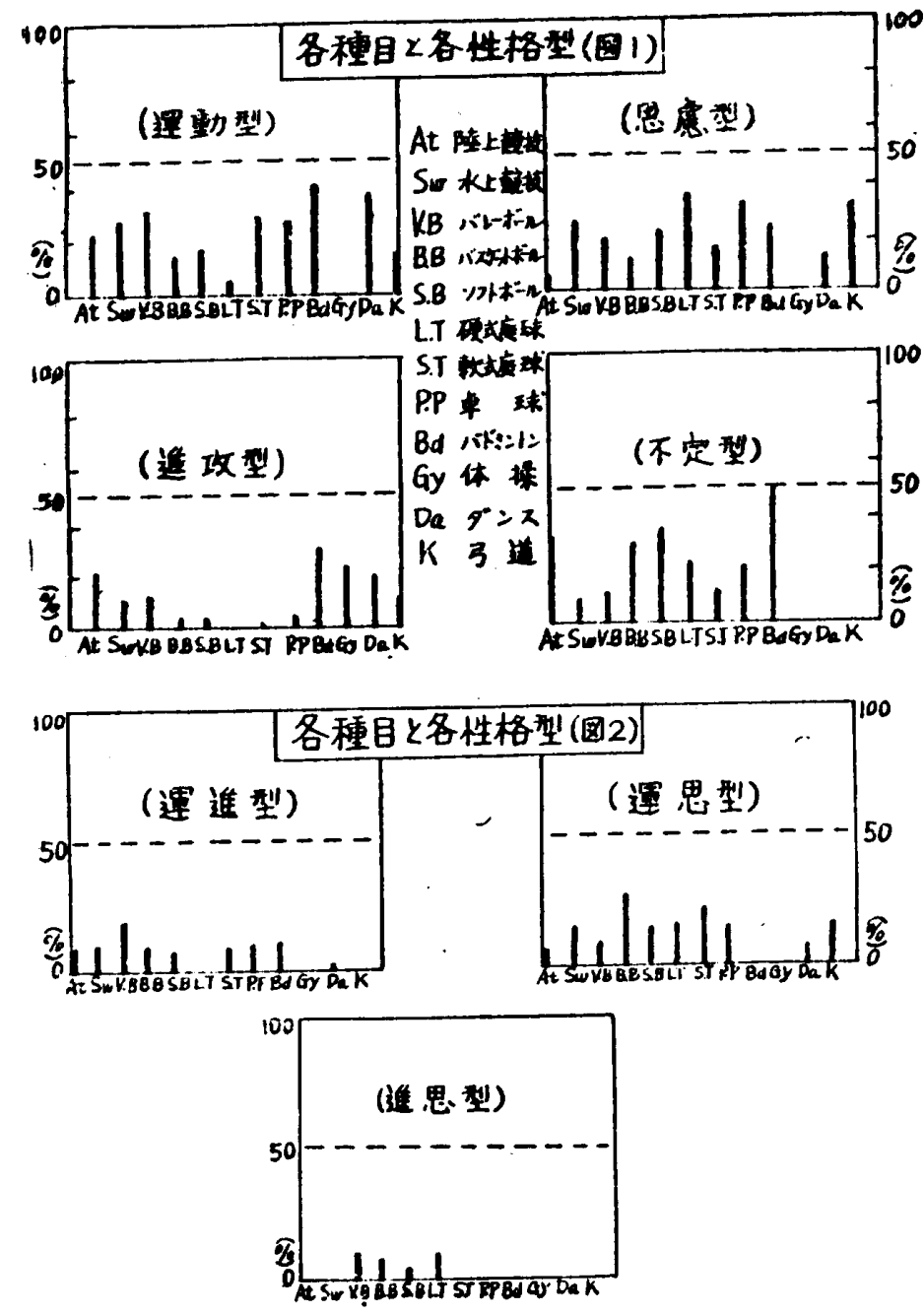

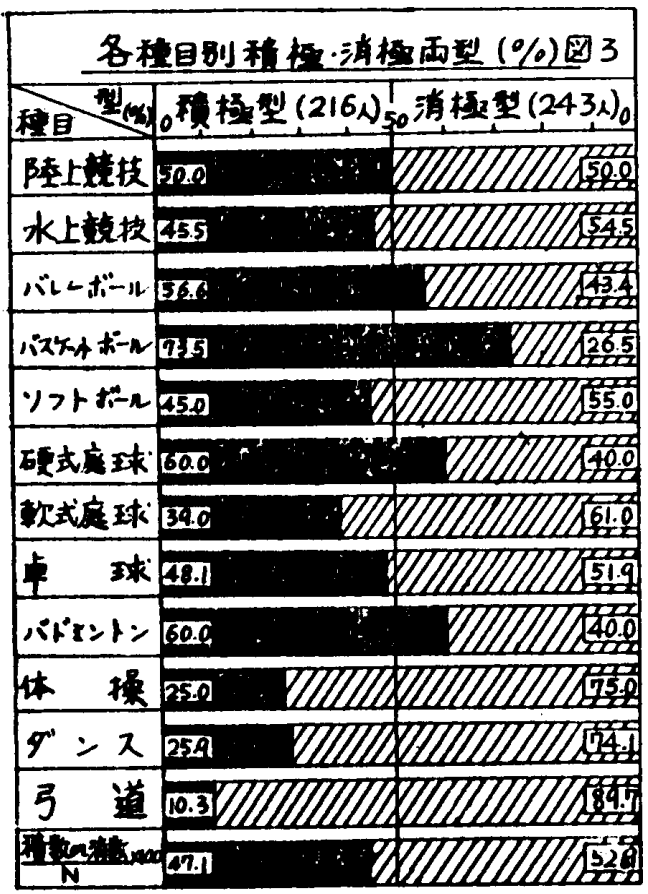

の二者に分類して見ると（祉. 第 3 図）大体においてて動

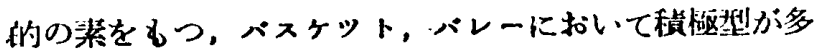

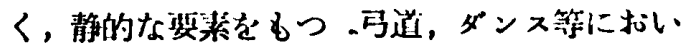
て消㥛型の頵问方現われている。

大代第一報は以上であるが、この佮直り結果

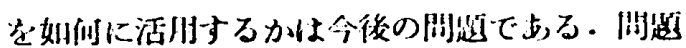

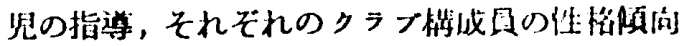
の祭知，这に括してスポーツ選択のガイダンス 久除性格り矮正，等々いくたの研究阙起がある と思了。

\section{運動選手に関する心理学的堛查の轺果に就}

いて（其の3）

\section{大紧工業大体青研究经}

官影治久，西山勝次，边禁治

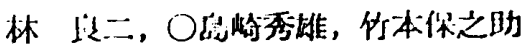

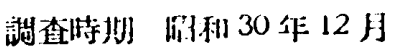

分法 证間紙法に上る

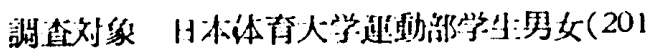
台)

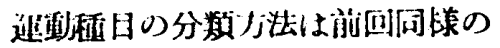

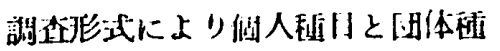
山に分けて行つた，

\begin{tabular}{|c|c|c|c|}
\hline \multirow[t]{2}{*}{ 個人䄸目 } & \multicolumn{2}{|c|}{ 淂子 (7) } & 女子 (4) \\
\hline & 陸上競技 & 67名 & 10 名 \\
\hline & 器械体操 & $9 "$ & $8 "$ \\
\hline & 娫 球 & $6 "$ & $3 "$ \\
\hline & 䂨 & $6 "$ & $7 "$ \\
\hline & 剣 & $7 "$ & \\
\hline & 米道 & $3 "$ & \\
\hline & レスทン & $9 "$ & \\
\hline
\end{tabular}

$$
\text { iit } 107 \text { 名 } 28 \text { 名 }
$$

咸体輀日 县子 (3) 女子 (1)

$$
\begin{aligned}
& \text { 籍 球 } 31 \text { 名 } \\
& \text { ラダピー } 15 \% \\
& \text { 排球 } 10 \% \\
& \text { 計 } 56 \text { 名 }
\end{aligned}
$$

調苦队容

従前までの一般大学の迎動選手及び工科采监科大学の

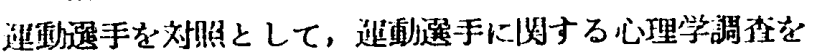
行つたが，今度は上部の大学と趣旨を巽にし，学校形態

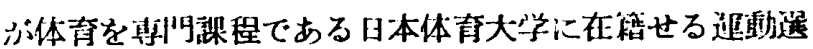
手の心理学的調查を行ひ，比较刘照の资料調查であつ

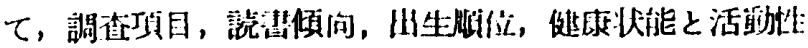

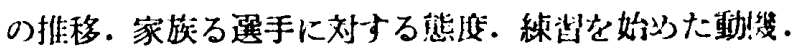

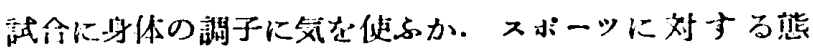

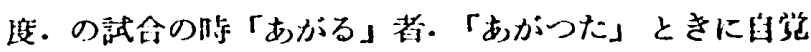
される钽候. 緑起をからぐか. 経起の具体例. 勉強と 